\title{
Abundance of Bacteria, the Cytophaga- Flavobacterium cluster and Archaea in cold oligotrophic waters and nepheloid layers of the Northwest Passage, Canadian Archipelago
}

\author{
Llyd E. Wells*, Jody W. Deming \\ School of Oceanography, University of Washington, Box 357940, Seattle, Washington 98195-7940, USA
}

\begin{abstract}
We used fluorescent in situ hybridization and epifluorescence microscopy to assess the distribution and diversity of pelagic microorganisms, specifically Bacteria, the Cytophaga-Flavobacterium $(\mathrm{CF})$ cluster and Archaea, in the cold $\left(-1.5\right.$ to $\left.3.5^{\circ} \mathrm{C}\right)$ and oligotrophic waters of the Northwest Passage, Canadian Arctic, during September 2000. Total cell abundance ranged from 1.23 to $6.56 \times 10^{5}$ cells $\mathrm{ml}^{-1}$, approximately half of which were hybridizable; Bacteria dominated the region (67 to $99.8 \%$ of hybridizable cells). CF were well-represented in the surface-water bacterioplankton, accounting for 9 to $41 \%$ of the total cell count (21 to $76 \%$ of hybridizable cells), but not in deeper populations: in nepheloid (particle-rich) layers, they accounted for only 1.6 to $5.4 \%$ of total cells (3.2 to $9.5 \%$ of hybridizable cells) despite the available substrata for attachment, a behavior common to this group. Over the entire data set, often highly significant $(\mathrm{p}<0.001)$ correlations with environmental variables, including oxygen, particulate organic nitrogen (PON) and chlorophyll a (chl a) (positive) and depth, salinity and macronutrients (negative) suggested the importance of CF as aerobic heterotrophic consumers in this environment. In marked contrast, Archaea were present at very low levels (0.1 to $2.6 \%$ of total cells; 0.2 to $4.6 \%$ of hybridizable cells) in the surface waters, becoming more abundant in nepheloid layers, where they accounted for 2.3 to $13 \%$ of total cells (3.9 to $33 \%$ of hybridizable cells). Archaea correlated highly significantly $(\mathrm{p}<0.001)$ with concentrations of particles and, in nepheloid layers, with PON. Over the entire data set, Archaea and Bacteria correlated significantly but oppositely to the same environmental variables of depth, salinity, oxygen and macro-nutrients, suggesting separate niches in this setting. In general, our results substantiate and extend the growing evidence for the numerical importance of CF in cold marine surface waters and further document the distribution and oceanographic context of the planktonic Archaea to include nepheloid layers.
\end{abstract}

KEY WORDS: Cytophaga-Flavobacterium $\cdot \mathrm{CF} \cdot$ Archaea $\cdot$ Nepheloid layer $\cdot$ Arctic $\cdot$ Particleassociated Bacteria · Amundsen Gulf

Resale or republication not permitted without written consent of the publisher

\section{INTRODUCTION}

Although of established importance in marine ecosystems for the biomass that they represent and the biogeochemical processes that they mediate, the majority (>99\%) of marine Bacteria and Archaea remain uncultivated (e.g. Giovannoni et al. 1990). Increasingly, molecular methods, particularly those based on the 16S ribosomal RNA gene, have been employed to circum-

*Email: chimera1@ocean.washington.edu vent this problem and to assess in situ abundances and (in some cases) processes of specific microbial groups (Amann et al. 1995). Using such techniques, members of the Cytophaga-Flavobacterium (CF) cluster have repeatedly emerged as abundant components of many marine ecosystems (Kirchman 2002), e.g. approximately $30 \%$ of total cells in temperate coastal waters (Cottrell \& Kirchman 2000). Well-known for their pro- 
clivity for attachment, constituents of the CytophagaFlavobacterium-Bacteroides phylum, including the $\mathrm{CF}$ cluster, represented 18 to $55 \%$ of nonplastid-like ribosomal sequences cloned from bacteria associated with marine snow in Californian coastal waters (DeLong et al. 1993) and in the Adriatic Sea (Rath et al. 1998). They were also members of the communities found attached to suspended particles in the Columbia River estuary (Crump et al. 1999) and to deposited sediments in the eastern Arctic (Ravenschlag et al. 2001). CF association with pelagic particles has not been addressed explicitly in high latitude waters; however, they appear again as abundant members of the bacterioplankton, e.g. up to $30 \%$ of total cells in North Sea surface waters (Glockner et al. 1999, Eilers et al. 2000) and up to $72 \%$ of the total bacterioplankton in Antarctic surface waters (Glockner et al. 1999). The numerical importance of the CF increased as a spring bloom peaked in the Chukchi Sea (Yager et al. 2001), where the CF were also a dominant group in the sea-ice cover (Junge et al. 2002). Together, these high-latitude results imply that CF play an important ecological role in polar marine environments, presumably as dominant heterotrophs (Kirchman 2002).

Using culture-independent molecular methods, the Archaea have also been shown to be numerically important and active components of the marine bacterioplankton (Ouverney \& Fuhrman 2000, Karner et al. 2001). They have now been documented across a wide range of estuarine (Crump \& Baross 2000) and marine environments, from the Atlantic, Pacific and Antarctic coasts (DeLong 1992, DeLong et al. 1994, Massana et al. 1997, Murray et al. 1998, 1999a) to the open ocean (DeLong et al. 1994, Karner et al. 2001) and deep sea (Karner et al. 2001). Recent estimates suggest that the Archaea constitute approximately $1 / 5$ of the total marine bacterioplankton, becoming increasingly abundant with depth (Karner et al. 2001). Yet, with the qualified exception of the Crenarchaeal sponge symbiont Cenarchaeum symbiosum (Preston et al. 1996), none of these organisms has been cultured; understanding the role of Archaea in the marine water column has so far relied exclusively on molecular techniques.

In Antarctic coastal waters, the application of molecular techniques has shown remarkable annual variability in the populations of Archaea, which vacillated from nearly undetectable levels in austral summer and autumn to a $1 / 4$ of the hybridization signal in winter and spring (Murray et al. 1998). Little information is available on the spatial or temporal distribution of Archaea at northern high latitudes, but here too Archaea have been found to represent significant components of the microbial population, e.g. off the Alaskan coast $(13.5 \%$ of the hybridization signal; DeLong et al. 1994) and in Arctic sediments (up to $5 \%$ of the total cells; Ravenschlag et al. 2001). Regardless of the marine environment considered, few data sets exist that combine fundamental oceanographic measurements (e.g. water temperature, salinity, macronutrient and chlorophyll a $[\mathrm{chl} a]$ concentrations, trans-

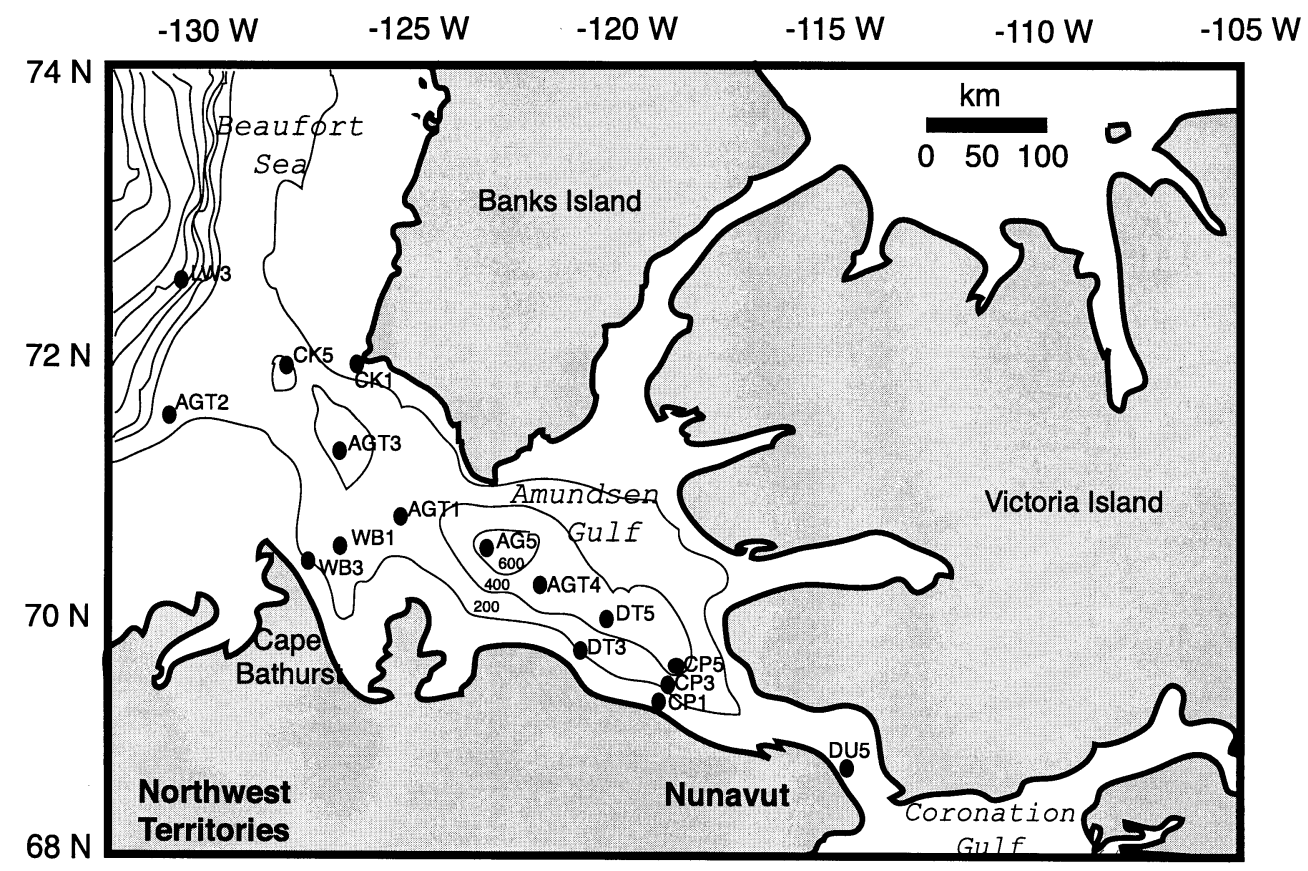

Fig. 1. Field site and stations. Stn DU5 is in Dolphin and Union Strait, which connects the Amundsen and Coronation Gulfs; Stn LW3 is at the sea-ice edge; all other stations are in Amundsen Gulf or the southeastern Beaufort Sea 
missivity) with the enumeration of Archaea, a paucity which further limits possibilities for inferring the role of Archaea in the ocean.

Based on the evidence for the potential significance of $\mathrm{CF}$ and Archaea among the high latitude marine bacterioplankton, we took advantage of a cruise of opportunity in September 2000 to assess their abundance, distribution and oceanographic context in waters of the Northwest Passage, Canadian Archipelago, an area that has received little oceanographic or microbiological attention. During the cruise, we learned that nepheloid layers, distinct regions of accumulated particulate material in the water column (McCave 1986), were encountered frequently in the Northwest Passage. Although numerous studies have demonstrated that, relative to the surrounding water, marine particles can be sites of increased microbial activity and organic transformation (e.g. Palumbo et al. 1984, Cho \& Azam 1988, Crump \& Baross 1996), even in the Arctic (Huston \& Deming 2002), no information was available on the quantitative representation of specific microbial groups in nepheloid layers, particlerich by definition. Thus, besides surveying the abundances of Bacteria, CF and Archaea in surface and some deeper waters of the Passage, we examined their concentrations in nepheloid layers.

\section{MATERIALS AND METHODS}

Field site and sampling. Sampling was conducted in the Northwest Passage (Fig. 1) from the Canadian Coast Guard icebreaker 'Sir Wilfrid Laurier' from 2 to 16 September 2000. Sixteen stations along 5 transects spanned coastal to offshore environments in Dolphin and Union Strait and Amundsen Gulf to the margins of the Beaufort Sea and the ice edge. A rosette equipped with 15 or 301 Niskin bottles, a CTD (Seabird SBE-19) and a transmissometer (Sea Tech, $25 \mathrm{~cm}$ pathlength, $660 \mathrm{~nm}$ wavelength) was lowered through the water column to the seafloor. Most samples were taken during descent at pre-assigned water depths chosen to maximize water column coverage. Samples for microbiological analysis were usually taken at $20 \mathrm{~m}$ depth, generally near the base of the pycnocline, to establish a foundation for comparisons. At some stations, other surface depths ( 7 to $42 \mathrm{~m}$ ) were sampled instead of or in addition to the $20 \mathrm{~m}$ sample. Nepheloid layers were detected in real time from shipboard transmissometry profiles (Fig. 2A). As the rosette returned to the surface, the nepheloid layers were sampled as close to the minimum transmissivity peak as possible. For comparative purposes, we were also able to take 3 samples of deep water that were not associated with nepheloid layers (Fig. 2B).

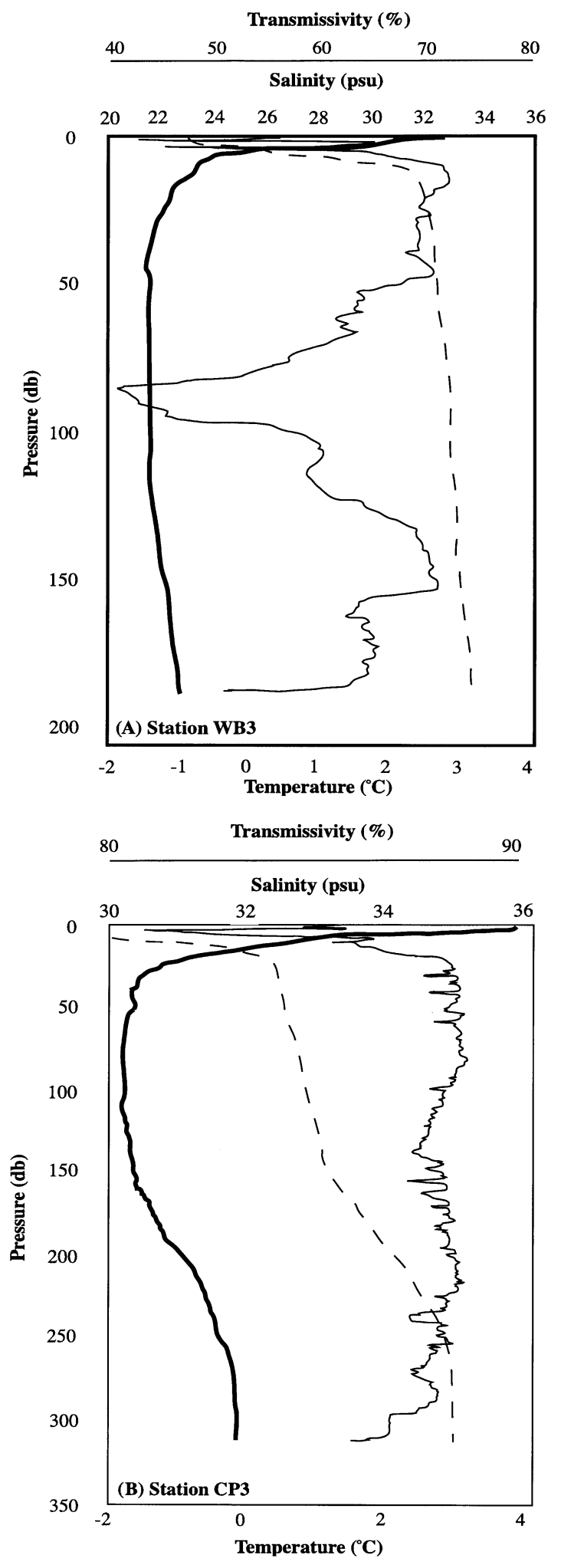

Fig. 2. Water column profiles showing temperature (bold lines) and salinity (dashed lines) distinctions between surface and deeper waters, in addition to (A) intermediate and benthic nepheloid layers (Stn WB3) and (B) the absence of a marked nepheloid layer (Stn CP3) via transmissometry 
Table 1. Probe specificity, sequence, corresponding E. coli positions and \% formamide used in hybridization

\begin{tabular}{|c|c|c|c|c|c|}
\hline Probe & Specificity & Sequence $\left(5^{\prime}-3^{\prime}\right)$ & $\begin{array}{l}\text { E. coli } \\
\text { position }\end{array}$ & $\begin{array}{c}\text { Formamide } \\
(\%)\end{array}$ & Source \\
\hline ARCH915 & Archaea & GTGCTCCCCCGCCAATTCCT & 915-935 & 20 & Stahl \& Amann (1991) \\
\hline EUB338 & Bacteria & GCTGCCTCCCGTAGGAGT & $338-355$ & 20 & Amann et al. (1990) \\
\hline CF319a & $\begin{array}{l}\text { Cytophaga-Flavobacterium } \\
\text { cluster }^{a}\end{array}$ & TGGTCCGTGTCTCAGTAC & $319-336$ & $35-40$ & Manz et al. (1996) \\
\hline
\end{tabular}

Once recovered, water was subsampled for shipboard or laboratory chemical analyses, including concentrations of macro-nutrients (nitrate, phosphate and silicate), salinity and dissolved oxygen (at the Institute of Ocean Sciences, Sydney, BC) and chl a (at the University of Tennessee), using standard techniques. Additionally, 250 to $300 \mathrm{ml}$ samples for measurement of particulate organic carbon (POC) and nitrogen (PON) were filtered gently onto muffled $25 \mathrm{~mm} \mathrm{GF/F}$ filters and frozen at $-20^{\circ} \mathrm{C}$ until laboratory analysis at the University of Washington. There they were dried at $60^{\circ} \mathrm{C}$ overnight, exposed to $\mathrm{HCl}$ vapors to remove inorganic carbon and then measured with a CHN analyzer (Model CEC440, Leeman Laboratories) with correction for blanks. In a number of cases, POC concentrations were below our detection limit of $33.0 \mu \mathrm{g} \mathrm{l}^{-1}$; only those samples with detectable amounts were used in later correlation analyses.

Microbial analyses by fluorescent in situ hybridization (FISH). For assessment of microbial diversity, duplicate $250 \mathrm{ml}$ water samples were filtered gently onto $0.22 \mu \mathrm{m}, 47 \mathrm{~mm}$ polycarbonate filters at near 0 temperatures in an unheated deck laboratory. The filters were fixed overnight in $0.5 \mathrm{ml} 4 \%$ PBS-buffered para-formaldehyde prior to storage in $70 \%$ ethanol at 2 to $4^{\circ} \mathrm{C}$ until analysis by FISH. For comparative purposes, duplicate $10 \mathrm{ml}$ water samples ('whole water samples') were taken at most stations, fixed with $2 \%$ (final concentration) formaldehyde and stored at 2 to $4^{\circ} \mathrm{C}$ until laboratory analysis. These samples were then filtered onto $0.22 \mu \mathrm{m}, 25 \mathrm{~mm}$ polycarbonate filters and enumerated as described below using the DNA stain 4,6-diamidino-2-phenylindole (DAPI).

For FISH, Cy-3 conjugated probes, specific to Bacteria (EUB338), Archaea (ARCH915) and the CF cluster (CF319a; also known to hybridize with some members of the Bacteroides; Manz et al. 1996) were synthesized by Operon Technologies. Conditions optimizing hybridization signal and probe specificity were determined using pure cultures of Bacteria, Archaea and CF, and were consistent with those used in the literature (e.g. Glockner et al. 1999; Table 1).

The FISH procedure employed with our field samples was similar to the hybridization approaches described by Glockner et al. (1996) and Maruyama \& Sunamura (2000), with a few adaptations described below. Filters from each sample were cut aseptically into 8 equal portions: 4 sections ( $1 / 2$ the filter) were used for FISH; the remaining 4 were stored for future work (as needed). Each section was dehydrated in sequential 2 min washes of 50,80 and $96 \%$ ethanol and mounted on cover slips. A $65 \mu \mathrm{l}$ aliquot of hybridization buffer $(0.9 \mathrm{M} \mathrm{NaCl}, 20 \mathrm{mM}$ Tris- $\mathrm{HCl}[\mathrm{pH}$ 8.0], $0.01 \%$ sodium dodecyl sulfate, $0.1 \mathrm{mg} \mathrm{ml}^{-1}$ polyadenylic acid, $0.2 \mathrm{mg} \mathrm{ml}^{-1} \mathrm{BSA}, 20$ or 35 to $40 \%$ formamide, depending on the probe; Table 1) was added, which was sufficient to cover the entire filter, and then incubated for $30 \mathrm{~min}$ at $46^{\circ} \mathrm{C}$. Following incubation, $250 \mathrm{ng}$ of $\mathrm{Cy}-3$ conjugated probe were added to the buffer and hybridized for $6 \mathrm{~h}$ at $46^{\circ} \mathrm{C}$. No probe was added to 1 filter slice per sample as an autofluorescence control. After hybridization, filter slices were washed for $20 \mathrm{~min}$ in $48^{\circ} \mathrm{C}$ wash buffer $(20 \mathrm{mM}$ Tris$\mathrm{HCl}$ [pH 8.0], $5 \mathrm{mM}$ EDTA, $0.01 \%$ SDS, 56 to $225 \mathrm{mM}$ $\mathrm{NaCl}$, depending on the formamide concentration during hybridization). Dried filters were mounted on slides with Vectashield mounting medium (Vector Laboratories) containing $1.5 \mu \mathrm{g} \mathrm{ml}^{-1}$ DAPI. Each hybridization was accompanied by positive and negative controls of pure cultures.

Filter slices were examined at $1563 \times$ magnification with a Zeiss Universal microscope using appropriate filter sets for DAPI and Cy-3 labeled cells (365/395 ex, $420 \mathrm{em}$ and 545/565 ex, $610 \mathrm{em}$, respectively). As described above, each sample was examined to enumerate Bacteria, Archaea, CF and autofluorescent cells. Per filter slice, DAPI-stained cells (= total cell count) were quantified in 20 fields; 50 fields were examined to quantify probed or autofluorescent cells. The numbers of autofluorescent cells, which were always $\ll 1 \%$ of the total counts, were subtracted from all probe counts, making the latter conservative (since any given autofluorescent cell can be either a Bacterium or an Archaeon, but not both). Filter portions from the same sample yielded comparable total cell numbers, indicating homogeneous distribution on the filter. We pooled the DAPI counts from the 4 filter slices to obtain the final, total cell abundance per sample. 
Total hybridizable cells were determined as the sum of Archaea and Bacteria. Twenty fields or a minimum of 200 DAPI-stained cells were enumerated in whole water samples.

Enumeration of yellow particles. Over the course of microscopic examination of filters, the presence of amorphous, yellow particles was noted. These predominantly pico- and nano-sized particles (0.2 to $20 \mu \mathrm{m}$ ) appeared bright yellow in DAPI-stained fields and were notably abundant in samples taken from nepheloid layers detected by transmissometry. Since these particles were clearly distinguished from cells on the filters, we enumerated them by epifluorescence microscopy, as others have reported previously (Mostajir et al. 1995, Brachvogel et al. 2001).

Statistical methods. Pearson correlation coefficients were determined for pairwise comparisons of microbiological (the means of duplicate samples) and environmental variables, with a significance level of $\mathrm{p}<0.05$ assessed by Student's 2-tailed $t$-test. Values of $\mathrm{p}<$ 0.001 were considered highly significant. Significant correlations were also examined graphically, to identify possible outliers or misleading correlations. Since a large number of correlations were performed, the probability of committing a Type I error for the entire data set may be underestimated by that probability for any individual correlation; hence, the tests cannot be considered definitive (as has been discussed for similar data sets; e.g. Murray et al. 1999b). Correlation analysis was performed on the data grouped as follows: surface-water samples, nepheloid-layer samples and samples pooled from all environments. The small number of deep samples prevented correlation analyses from being performed separately with this group. Due to the uneven sample sizes and low power of corresponding nonparametric tests, we did not consider multiple comparisons among surface, nepheloid and deep samples. Instead, we restricted our comparison to nepheloid and deep samples, using the nonparametric Mann-Whitney $U$-test to examine the 2-tailed null hypothesis that no difference existed between them.

\section{RESULTS}

\section{Water column characteristics}

The 16 stations sampled ranged from shallow coastal environments with strong freshwater inputs (from rivers and ice-melt) to deeper (up to $666 \mathrm{~m}$ ) stations in the middle of Amundsen Gulf (Fig. 1). The water column appeared to be stably stratified throughout the study area (Fig. 2). Two types of nepheloid layers were detected by transmissometry and sampled: most were associated with the bottom (i.e. benthic nepheloid layers), but an intermediate nepheloid layer was also sampled (Fig. 2A). As judged from the transmissometry profiles, the vertical dimension of the nepheloid layers ranged from $\sim 10 \mathrm{~m}$ to over $100 \mathrm{~m}$. Sampling depths of nepheloid layers and deep waters (Fig. 2B) ranged from 92 to $600 \mathrm{~m}$.

The surface waters sampled were distinguished from the nepheloid and deep samples (Table 2) by depth but also by their wider range of temperatures (from -1.5 to 3.5 vs -1.5 to $0.3^{\circ} \mathrm{C}$ ) and salinities (from 26.1 to 32.4 vs 32.9 to $34.8 \mathrm{psu})$, generally low nitrate and phosphate concentrations (medians of 0.02 and $0.8 \mu \mathrm{M}$, respectively, with nitrate undetectable at 6 stations), higher chl a concentrations (which were nevertheless low, me-

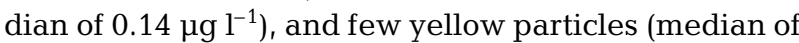
50 particles $\mathrm{ml}^{-1}$ ). In the nepheloid and deep waters, concentrations of nitrate and phosphate (medians of 16 and $1.2 \mu \mathrm{M}$, respectively) were higher than in surface waters, while chl a concentrations were lower (median of $0.02 \mathrm{~g} \mathrm{~g} \mathrm{l}^{-1}$ ), as expected at depth in a stratified system (Table 2). The nepheloid and deep water samples, however, were indistinguishable from each

Table 2. Summary of environmental variables for the 3 types of samples examined: surface $(\mathrm{n}=18)$, nepheloid $(\mathrm{n}=8)$ and deep $(n=3)$ waters. b.d.: below detection

\begin{tabular}{|c|c|c|c|}
\hline \multirow[t]{2}{*}{ Environmental variable } & & \multirow{2}{*}{$\begin{array}{l}\text { Median (range) } \\
\text { Nepheloid layers }\end{array}$} & \multirow[b]{2}{*}{ Deep waters } \\
\hline & Surface waters & & \\
\hline Depth (m) & $20(7-42)$ & $422(92-600)$ & $310(150-500)$ \\
\hline Temperature $\left({ }^{\circ} \mathrm{C}\right)$ & $-0.64(-1.5-3.5)$ & $0.23(-1.5-0.3)$ & $0.14(-1.5-0.2)$ \\
\hline Salinity (psu) & $30.93(26.10-32.35)$ & $34.74(32.92-34.84)$ & $34.71(33.06-34.76)$ \\
\hline $\mathrm{O}_{2}(\mu \mathrm{M})$ & $405(343-419)$ & $254(228-291)$ & $231(224-281)$ \\
\hline $\mathrm{NO}_{3}(\mu \mathrm{M})$ & $0.02(0.00-15.1)$ & $15.9(14.1-16.8)$ & $16.4(14.1-16.9)$ \\
\hline $\mathrm{PO}_{4}(\mu \mathrm{M})$ & $0.8(0.6-1.2)$ & $1.2(1.0-1.9)$ & $1.3(1.3-1.8)$ \\
\hline $\mathrm{SiO}_{4}(\mu \mathrm{M})$ & $4.7(2.4-21.0)$ & $26.6(15.1-32.4)$ & $29.2(27.3-32.4)$ \\
\hline Particles $\left(\mathrm{ml}^{-1}\right)$ & $50(0-1000)$ & $3550(1500-9000)$ & $600(200-600)$ \\
\hline POC $\left(\mu \mathrm{g} \mathrm{l}^{-1}\right)$ & 43.2 (b.d.-83.1) & 40.6 (b.d.-73.0) & $<33.0$ (b.d.-38.6) \\
\hline PON $\left(\mu \mathrm{g} \mathrm{l}^{-1}\right)$ & $12.0(8.0-17.6)$ & $8.8(5.0-18.0)$ & $7.0(6.5-7.4)$ \\
\hline Chl a $\left(\mu g \mathrm{l}^{-1}\right)$ & $0.14(0.02-0.59)$ & $0.02(0.001-0.08)$ & $0.02(0.01-0.03)$ \\
\hline
\end{tabular}


other statistically (Mann-Whitney $U$-test, $\mathrm{p}>0.05$ ) by any environmental variable except particle concentration, which was significantly higher in nepheloid layers (Table 2; Mann-Whitney $U$-test, $\mathrm{p}=0.02$ ). In the nepheloid samples, particle concentrations correlated significantly $(\mathrm{p}<0.05)$ with phosphate, silicate and chl a (all positively), and with depth, temperature and salinity (negatively). Particle concentration did not correlate significantly with depth above bottom.

\section{Enumeration of total cells}

To assess the quantitative accuracy of cell counts from fixed filters passed through FISH procedures, we compared DAPI counts from FISH to those from the whole water samples. The positive correlation between abundances determined by these 2 methods was highly significant $(\mathrm{r}=0.81, \mathrm{n}=26, \mathrm{p}<0.001$ ), with concentrations of filter-fixed cells higher by a factor of approximately 1.4. Based on these results and for consistency with the domain- and phylum-specific counts, we used the DAPI counts from the FISH procedure as the measure of total cell concentrations.

Concentrations of bacterioplankton enumerated by DAPI staining and epifluorescence microscopy ranged from 1.23 to $6.56 \times 10^{5}$ cells $\mathrm{ml}^{-1}$ in surface waters (Table 3 ); nepheloid and deep samples generally had smaller populations (1.37 to $2.49 \times 10^{5}$ cells $\mathrm{ml}^{-1}$; Table 3). Although size was not quantified

Table 3. Microbial populations (mean of duplicate samples at a given depth) in each of the 3 types of environments examined (Table 2), with stations ordered from east to west in the sampling region (Fig. 1). \% HYB: fraction of total cells that hybridized with 1 of the 2 domain-level probes; \% of HYB: fraction of the hybridizable cells represented by a given group (Bacteria, CF or Archaea); bold: coastal stations (within $40 \mathrm{~km}$ of shore); nd: not determined

\begin{tabular}{|c|c|c|c|c|c|c|c|c|c|c|c|c|}
\hline \multirow[t]{2}{*}{ Stn } & \multirow{2}{*}{$\begin{array}{l}\text { Depth } \\
\text { (m) }\end{array}$} & \multicolumn{2}{|c|}{-Total cells _— } & \multicolumn{3}{|c|}{ Bacteria- } & \multirow{2}{*}{$\overline{\left(\times 10^{4} \mathrm{ml}^{-1}\right)}$} & \multicolumn{2}{|c|}{$\mathrm{CF}-$} & \multicolumn{3}{|c|}{ Archaea } \\
\hline & & $\left(\times 10^{5} \mathrm{ml}^{-1}\right)$ & $\begin{array}{c}(\% \\
\text { HYB })\end{array}$ & $\left(\times 10^{5} \mathrm{ml}^{-1}\right)$ & $\begin{array}{l}\text { (\% of } \\
\text { total) }\end{array}$ & $\begin{array}{l}\text { (\% of } \\
\text { HYB) }\end{array}$ & & $\begin{array}{l}\text { (\% of } \\
\text { total) }\end{array}$ & $\begin{array}{l}\text { (\% of } \\
\text { HYB) }\end{array}$ & $\left(\times 10^{3} \mathrm{ml}^{-1}\right)$ & $\begin{array}{l}(\% \text { of } \\
\text { total) }\end{array}$ & $\begin{array}{l}\text { (\% of } \\
\text { HYB) }\end{array}$ \\
\hline \multicolumn{13}{|c|}{ Surface water } \\
\hline DU5 & 7 & 1.23 & 66 & 0.81 & 66 & 99 & 4.73 & 39 & 58 & 0.42 & 0.3 & 0.5 \\
\hline CP1 & 20 & 3.09 & 65 & 1.97 & 64 & 97 & nd & nd & nd & 5.27 & 1.7 & 2.6 \\
\hline CP3 & 20 & 2.85 & 22 & 0.60 & 21 & 95 & 4.38 & 15 & 70 & 2.85 & 1.0 & 4.5 \\
\hline CP5 & 20 & 2.27 & 52 & 1.16 & 50 & 95 & 9.23 & 41 & 76 & 5.36 & 2.4 & 4.4 \\
\hline DT3 & 20 & 2.71 & 45 & 1.15 & 43 & 95 & nd & nd & nd & 5.48 & 2.0 & 4.6 \\
\hline DT5 & 20 & 5.53 & 51 & 1.83 & 51 & 100 & 8.36 & 15 & 30 & 0.75 & 0.1 & 0.3 \\
\hline AGT4 & 20 & 4.57 & 50 & 2.28 & 50 & 100 & 16.3 & 36 & 71 & 0.89 & 0.2 & 0.4 \\
\hline AG5 & 10 & 6.56 & 60 & 3.94 & 60 & 100 & 12.5 & 19 & 32 & 0.61 & 0.1 & 0.2 \\
\hline AG5 & 20 & 4.94 & 59 & 3.27 & 59 & 99 & nd & nd & nd & 1.76 & 0.4 & 0.6 \\
\hline WB3 & 20 & 3.54 & 26 & 1.01 & 26 & 99 & 3.44 & 10 & 37 & 0.65 & 0.2 & 0.7 \\
\hline WB1 & 20 & 4.32 & 43 & 1.72 & 43 & 100 & 6.11 & 14 & 35 & 0.92 & 0.2 & 0.5 \\
\hline WB1 & 42 & 2.15 & 59 & 1.22 & 56 & 96 & 4.40 & 21 & 35 & 5.51 & 2.6 & 4.3 \\
\hline AGT1 & 20 & 5.42 & 75 & 3.23 & 75 & 100 & 10.5 & 19 & 26 & 1.85 & 0.3 & 0.5 \\
\hline AGT3 & 20 & 5.21 & 64 & 3.28 & 63 & 99 & 7.06 & 14 & 21 & 3.84 & 0.7 & 1.2 \\
\hline CK1 & 20 & 3.27 & 52 & 1.64 & 52 & 100 & nd & nd & nd & 0.34 & 0.1 & 0.2 \\
\hline CK5 & 20 & 4.24 & 58 & 2.39 & 57 & 99 & 10.9 & 26 & 45 & 3.44 & 0.8 & 1.4 \\
\hline AGT2 & 15 & 3.85 & 59 & 2.28 & 59 & 100 & 6.95 & 18 & 30 & 0.52 & 0.1 & 0.2 \\
\hline LW3 & 33 & 5.11 & 38 & 1.85 & 36 & 96 & 4.60 & 9.0 & 24 & 7.15 & 1.4 & 3.7 \\
\hline Medians & & 4.05 & 55 & 1.84 & 54 & 99 & 7.01 & 19 & 35 & 1.81 & 0.4 & 0.7 \\
\hline \multicolumn{13}{|c|}{ Nepheloid layer } \\
\hline DT5 & 480 & 2.49 & 42 & 1.00 & 39 & 93 & 0.98 & 3.9 & 9.2 & 7.40 & 3.0 & 6.9 \\
\hline AGT4 & 431 & 2.27 & 74 & 1.64 & 71 & 96 & 0.55 & 2.4 & 3.2 & 6.71 & 3.0 & 3.9 \\
\hline AG5 & 600 & 1.90 & 48 & 0.78 & 41 & 86 & 0.59 & 3.1 & 6.5 & 12.7 & 6.7 & 14 \\
\hline WB3 & 92 & 1.39 & 37 & 0.42 & 31 & 84 & 0.40 & 2.9 & 8.0 & 7.99 & 5.7 & 16 \\
\hline WB3 & 160 & 1.55 & 39 & 0.42 & 26 & 67 & 0.58 & 3.7 & 9.5 & 19.8 & 13 & 33 \\
\hline WB1 & 310 & 2.19 & 35 & 0.71 & 33 & 94 & 0.35 & 1.6 & 4.6 & 4.97 & 2.3 & 6.5 \\
\hline AGT3 & 446 & 2.32 & 47 & 0.89 & 38 & 81 & 0.62 & 2.7 & 5.7 & 20.6 & 8.9 & 19 \\
\hline CK5 & 413 & 1.68 & 57 & 0.91 & 53 & 93 & 0.90 & 5.4 & 9.3 & 6.82 & 4.1 & 7.0 \\
\hline Medians & & 2.05 & 45 & 0.84 & 39 & 90 & 0.59 & 3.0 & 7.3 & 7.70 & 4.9 & 11 \\
\hline \multicolumn{13}{|c|}{ Deep water } \\
\hline CP3 & 310 & 1.94 & 31 & 0.61 & 30 & 98 & 0.47 & 2.4 & 7.6 & 1.36 & 0.7 & 2.2 \\
\hline CP5 & 150 & 1.37 & 39 & 0.50 & 36 & 92 & 1.48 & 11 & 27 & 4.53 & 3.3 & 8.4 \\
\hline CP5 & 500 & 1.94 & 21 & 0.38 & 20 & 96 & 0.58 & 3.0 & 15 & 1.45 & 0.7 & 3.7 \\
\hline Medians & & 1.94 & 31 & 0.50 & 30 & 96 & 0.58 & 3.0 & 15 & 1.45 & 0.7 & 3.7 \\
\hline
\end{tabular}


Table 4. Pearson correlation coefficients $(\mathrm{r})$ for significant $(\mathrm{p}<0.05)$ correlations detected between microbial and environmental variables in all samples, using Student's 2-tailed $t$-test. Environmental variables tested but not yielding significant correlations included temperature, POC and C:N ratio. Bold: negative correlations; ${ }^{*}$ highly significant $(\mathrm{p}<0.001)$; ns: not significant

\begin{tabular}{|c|c|c|c|c|c|}
\hline Environmental variables & Total cells & Hybridizable cells & $\begin{array}{c}\text { Microbial variables } \\
\text { Bacteria }\end{array}$ & $\mathrm{CF}$ & Archaea \\
\hline Depth & -0.52 & -0.47 & -0.48 & $-0.68^{*, b}$ & 0.49 \\
\hline Salinity & -0.47 & -0.51 & -0.52 & $-0.67^{*, b}$ & 0.53 \\
\hline $\mathrm{O}_{2}$ & $0.70^{*}$ & $0.61^{*}$ & $0.63^{*}$ & $0.83^{*, b}$ & -0.51 \\
\hline $\mathrm{NO}_{3}$ & $-0.72^{*}$ & $-0.64^{*}$ & $-0.66^{*}$ & $-0.81^{*, \mathrm{~b}}$ & $0.58^{\mathrm{a}}$ \\
\hline $\mathrm{PO}_{4}$ & $-0.60^{*}$ & $-0.58^{*}$ & $-0.59^{*}$ & $-0.63^{*, \mathrm{~b}}$ & $0.51^{\mathrm{a}}$ \\
\hline $\mathrm{SiO}_{4}$ & $-0.68^{*}$ & $-0.63^{*}$ & $-0.64^{*}$ & $-0.78^{*, b}$ & $0.51^{\mathrm{a}}$ \\
\hline Particles & -0.45 & ns & -0.41 & $-0.54^{b}$ & $0.73^{*, \mathrm{a}}$ \\
\hline PON & 0.60 & 0.57 & 0.57 & $0.63^{\mathrm{b}}$ & ns \\
\hline Chl a & $\mathrm{ns}$ & ns & $\mathrm{ns}$ & $\mathrm{ns}^{\mathrm{b}}$ & -0.40 \\
\hline
\end{tabular}

systematically, the cells were commonly small in all samples, with the majority having longest dimensions of 0.4 to $0.7 \mu \mathrm{m}$. For surface waters, the only environmental variables with which total cell concentrations correlated significantly were oxygen concentration $(\mathrm{r}=0.52, \mathrm{p}<0.05)$ and $\mathrm{chl} a(\mathrm{r}=-0.54, \mathrm{p}<0.05)$. Of the other microbial variables, total cell concentrations correlated positively with hybridizable cell concentrations ( $\mathrm{r}=0.82, \mathrm{p}<0.001$ ) and negatively with the archaeal percentage of total cells (r $=-0.52, \mathrm{p}<0.05)$. Additionally, total cell concentrations nearshore $(<40 \mathrm{~km})$ were lower than those in the central waters of the Passage (2-tailed $t$-test, $\mathrm{p}<0.001$; Table 3). In nepheloid samples, total cell concentrations correlated significantly only with temperature $(\mathrm{r}=0.76, \mathrm{p}<0.05)$ and salinity $(\mathrm{r}=$ $0.75, \mathrm{p}<0.05)$.

\section{FISH}

Approximately $1 / 2$ the cells from all samples were hybridizable (Table 3). In surface waters, hybridizable cell concentrations correlated positively with PON ( $\mathrm{r}=0.51, \mathrm{p}<$ 0.05) and CF concentrations ( $\mathrm{r}=0.61, \mathrm{p}<$ 0.05), in addition to total cell abundance as noted above. Hybridizable cell concentrations in nepheloid layers showed no significant correlations with any other variable but were higher than those in deep waters $(p=0.02$, Mann-Whitney $U$-test). No obvious distinction in cell size or shape was observed between hybridizable cells and those that did not hybridize.

\section{Abundance and distribution of Bacteria and CF}

FISH demonstrated that Bacteria dominated the hybridizable cells in all cases, accounting for 67 to $99.8 \%$ of the hybridizable cells at all sampling depths (Table 3) and showing most of the same correlations. In surface waters, CF ranged from 3.44 to $16.3 \times 10^{4}$ cells $\mathrm{ml}^{-1}$ and comprised a large fraction of the hybridizable cells (21 to $76 \%$; Table 3). Surface-water CF abun-

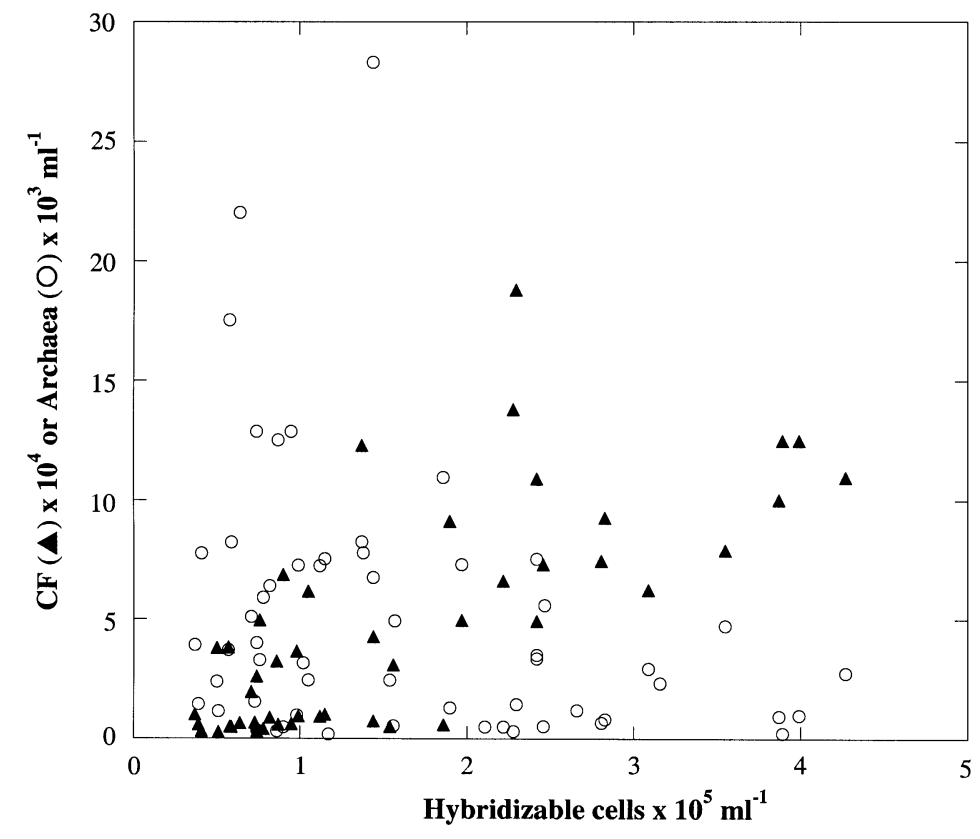

Fig. 3. Relationship between $\mathrm{CF}(\mathbf{\Delta})$ or Archaea $(O)$ and total hybridizable cells (Bacteria plus Archaea) for all samples (each duplicate plotted separately). As discussed in the text, $\mathrm{CF}$ and hybridizable cell concentrations correlated positively $(\mathrm{r}=0.76, \mathrm{p}<0.05)$; concentrations of Archaea and hybridizable cells correlated negatively $(r=-0.35,0.05<p<0.10)$ 
dance correlated positively with POC $(\mathrm{r}=0.63, \mathrm{p}<$ $0.05)$ and PON ( $r=0.55, \mathrm{p}<0.05)$, in addition to the concentration of hybridizable cells as noted earlier. In nepheloid layers, $\mathrm{CF}$ concentrations ranged from 3.5 to $9.8 \times 10^{3}$ cells ml$^{-1}$ or 3.2 to $9.5 \%$ of hybridizable cells (Table 3); no significant correlation with any variable was found. In deep samples, CF ranged from 4.7 to $14.8 \times 10^{3}$ cells $\mathrm{ml}^{-1}$ or 7.6 to $27 \%$ of hybridizable cells (Table 3).

When samples from all environments were pooled, $\mathrm{CF}$ concentrations showed highly significant $(\mathrm{p}<$ 0.001) negative correlations with depth, salinity and macronutrient variables, and a highly significant positive correlation with oxygen (Table 4). CF also increased significantly $(\mathrm{p}<0.05)$ with PON and, when considered as a fraction of the total and hybridizable cells, with chl a concentration; they decreased, however, with particle concentration (Table 4). CF correlated with all other microbial variables examined: positively and highly significantly $(p<0.001)$ with concentrations of total cells $(r=0.76)$, of hybridizable cells $(r=0.76$; Fig. 3) and of Bacteria $(r=0.82)$; negatively with the concentration of Archaea $(r=-0.50, p<0.05)$. Most of the same correlations were observed if derived variables for $\mathrm{CF}$ (the fraction of total or hybridizable cells) were considered instead (see footnote to Table 4). When relationships were examined together (Table 4), CF, Bacteria, hybridizable cell and total cell concentrations all correlated significantly and similarly with most of the same environmental variables (Table $4)$.

\section{Abundance and distribution of Archaea}

In surface waters, the concentrations of Archaea were low, ranging from 0.34 to $7.15 \times 10^{3}$ cells $\mathrm{ml}^{-1}$ with a median of $1.81 \times 10^{3}$ cells $\mathrm{ml}^{-1}$ (Table 3 ). They constituted less than $1 \%$ of the total or hybridizable cells (ranges of 0.1 to 2.6 and 0.2 to $4.6 \%$, respectively; Table 3). The abundance of Archaea in surface-water samples correlated positively with depth and macronutrient concentrations $(\mathrm{p}<0.05)$ and with salinity $(\mathrm{p}<$ 0.054).

In contrast to surface waters, concentrations of Archaea in nepheloid layers were higher, ranging from

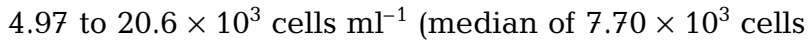
$\mathrm{ml}^{-1}$; Table 3 ). Up to $13 \%$ of the total cells hybridized with ARCH915, equivalent to $33 \%$ of the hybridizable cells (Table 3). The abundance of Archaea correlated positively and highly significantly with PON ( $\mathrm{r}=0.97$, $\mathrm{p}<0.001)$. The archaeal fraction of hybridizable cells also increased significantly with the number of yellow particles quantified by DAPI $(r=0.76, p<0.05)$. The median concentration of Archaea $\left(1.45 \times 10^{3}\right.$ cells ml $\left.{ }^{-1}\right)$ in deep samples was significantly lower than in nepheloid layers (Mann-Whitney $U$-test, $p=0.02$ ) and represented a smaller percentage of the hybridizable cells (3.7\%; Table 3$)$.

Pooling data on Archaea from all environments revealed significant positive correlations between abundance of Archaea and depth, salinity and macronutrient variables (Table 4). The additional positive correlation observed between abundance of Archaea (as well as the archaeal fraction of total and hybridizable cells) and particle concentration was highly significant $(p<0.001 ;$ Table 4). Negative correlations were detected between abundance of Archaea and oxygen and chl a (Table 4), as well as total cells ( $\mathrm{r}=$ $-0.43, \mathrm{p}<0.05)$. In general, use of derived archaeal variables either did not alter the significance of a correlation or else increased it (e.g. the archaeal fractions of total and of hybridizable cells yielded highly significant positive relationships with macronutrient concentrations; Table 4). A striking observation from the pooled samples is that the concentration of Archaea, compared to all other microbial variables, shows significant but opposite correlations to the major environmental variables considered in this study (Table 4).

\section{DISCUSSION}

\section{Surface water}

Little oceanographic information is available for Amundsen Gulf and Dolphin and Union Strait, where the majority of our sampling took place. Previous work has focused mainly to the west, in the Beaufort Sea (e.g. Iseki et al. 1987, Macdonald et al. 1998) and near the Mackenzie River delta (e.g. Macdonald et al. 1989, Omstedt et al. 1994), as well as to the east, in Resolute Passage and beyond (e.g. Pomeroy et al. 1990, Huston \& Deming 2002). During our sampling period, salient features of the region included low surface-water salinities, reflecting the important freshwater inputs of melting sea ice and rivers (Carmack \& Macdonald 2002; Fig. 2, Table 2), and macro-nutrient and chl a concentrations indicative of oligotrophy (Table 2). The commonly small cell sizes we observed were also consistent with an oligotrophic environment (Morita 1997).

Although the total cell abundances we measured (median of $4.05 \times 10^{5}$ cells $\mathrm{ml}^{-1}$ ) are low compared to most temperate coastal environments, they fall within the range reported for the nearby Beaufort Sea (3.7 to $4.5 \times 10^{5}$ cells ml ${ }^{-1}$; Griffiths et al. 1978) and Mackenzie River estuary $\left(1 \times 10^{4}\right.$ to $5 \times 10^{6}$ cells ml ${ }^{-1}$; Parsons et al. $1988,1989)$, and for the more distant Chukchi Sea $(2.0$ to $9.4 \times 10^{5}$ cells $\mathrm{ml}^{-1}$; Yager et al. 2001) in mid-to-late summer. Parsons et al. (1988) reported that bacterial 
production nearshore was much lower than in more oceanic provinces of the Mackenzie River estuary. Although possible explanations, including differences in terrigenous input and ice dynamics between the 2 regimes, have not been tested rigorously, our finding of significantly higher cell concentrations in off-shore surface waters than in coastal waters (Table 3) supports the pattern they observed.

The sizeable fraction (approximately $1 / 2$ ) of the microbial community in the Northwest Passage that did not hybridize with either of the 2 domain-level probes is consistent with the oligotrophic nature of the environment during our sampling period. Similarly low or lower fractions of hybridizable cells have been reported in other mesotrophic or oligotrophic systems, including those in cold environments (Alfreider et al. 1996, DeLong et al. 1999, Glockner et al. 1999). Compounding the effect of oligotrophy in our study may be an enhanced bacterial substrate requirement at low temperatures (Li \& Dickie 1984, Pomeroy \& Deibel 1986, Pomeroy \& Wiebe 2001). Since the threshold signal of FISH depends on the cellular rRNA content (e.g. Kemp et al. 1993), the hybridizable cells can be interpreted as an indicator of the more active cells in the community. Such an interpretation of FISH results has been shown to correspond well with autoradiography, another measure of cellular activity (Karner \& Fuhrman 1997). Thus, the low fraction of hybridizable cells that we observed in the Northwest Passage at the end of summer likely reflects a similarly low fraction of active cells, due to the combination of oligotrophy and cold temperature.

We cannot rule out the possibility, however, that the 2 domain-level probes missed important microbial constituents. Recent work has indicated that the probe EUB338 may fail to hybridize with many of the Planctomycetales and Verrucomicrobia (Daims et al. 1999). Studies of Antarctic and North Sea surface waters and of Arctic sediments have documented that the Planctomycetales are generally small components of the microbial communities there $(<4 \%$ of the total cells; Glockner et al. 1999, Ravenschlag et al. 2001). Less is known about the distribution of the Verrucomicrobia in high latitude oceans, but they have been detected in the Arctic (6\% of clone sequences; Bano \& Hollibaugh 2002). Since most of the cells that we observed were very small $(\sim 0.5 \mu \mathrm{m})$, the majority of the unhybridized cells were unlikely to have been Eukarya.

CF were abundant members of the surface bacterioplankton representing approximately $20 \%$ of the total cells or $35 \%$ of the more active ones. At 3 stations in the eastern Amundsen Gulf (AGT4, CP3 and CP5; Fig. 1, Table 3), CF were $\geq 70 \%$ of the hybridizable cells. These results demonstrate that $\mathrm{CF}$ are numerically important members of the surface bacterioplank- ton community in this environment, in accordance with literature-based expectations. The significant positive correlations of $\mathrm{CF}$ with $\mathrm{POC}$, $\mathrm{PON}$ and hybridizable cells all suggest that $\mathrm{CF}$ abundance may reflect to a large extent their success as heterotrophic competitors, as others have discussed (Kirchman 2002).

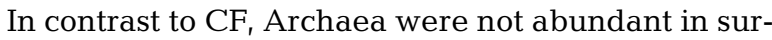
face waters, typically representing less than $1 \%$ of the total $(0.1$ to $2.6 \%$ ) or hybridizable ( 0.2 to $4.6 \%$ ) bacterioplankton. These low percentages are similar to those reported over 2 austral summers for coastal Antarctic waters $(0.2$ to $1.3 \%$ of the hybridization signal in 1994 to 1995 , Murray et al. 1999 a; $2.3 \pm 2.4 \%$ in 1996 to 1997, Murray et al. 1998). During winter and spring, however, the Antarctic Archaea became substantial components (approximately $1 / 3$ ) of the surfacewater hybridization signal (Murray et al. 1998). Surface-water Archaea in the Northwest Passage became significantly more abundant with conditions characteristic of deep waters, such as higher macro-nutrients and salinity (similar correlations were seen with pooled data; Table 4) and tended to increase with decreasing temperature. These relationships may imply a deep-seeding source for the surface-water Archaea in this Arctic region, as also suggested for surfacedwelling Crenarchaeota found in the Santa Barbara Channel (Murray et al. 1999b).

\section{Nepheloid layers}

Nepheloid layers of varying extent are common oceanic features of coastal environments, continental shelves and slopes and the deep sea (McCave 1986, Azetsu-Scott et al. 1995). Generally, they are associated with the bottom (benthic nepheloid layers), where they form predominantly by sediment resuspension caused by turbulence or internal waves. Other formation mechanisms are also possible, however, including biological processes such as bloom sedimentation or physical processes that reflect strong pycnoclines or turbid water intrusions from rivers (Azetsu-Scott et al. 1995). Coastal erosion (Macdonald et al. 1998), scouring by sea-ice keels (Reimnitz et al. 1987, Hequette et al. 1995) and storm resuspension (Hill \& Nadeau 1989) have been documented as important particle sources on the Canadian Arctic Shelf. Extensive shipboard measurements to determine the source and mechanistic origin of the nepheloid layers detected during our cruise were not possible; however, particle concentrations in the nepheloid samples we collected did not correlate with depth above bottom, as might be expected were they resuspended bottom sediments. That 1 water column profile (Fig. 2A) exhibited both benthic and intermediate nepheloid layers suggests 
that the layers cannot easily be explained by any single source or mechanism.

Other studies have suggested that nepheloid layers can be nutritionally enriched environments compared to the surface or adjacent deep waters (Kamykowski \& Bird 1981, Checkley et al. 1992, Boetius et al. 2000). Benthic nepheloid layers examined in the Gulf of Maine (Townsend et al. 1992), Kiel Bight (Ritzrau \& Graf 1992), the deep Arabian Sea (Boetius et al. 2000) and the Northeast Water, an Arctic polynya (Ritzrau \& Thomsen 1997, Ritzrau et al. 1997), all supported greater bacterial abundance and/or biomass relative to nearby deep waters. The following are consistent with the possible nutritional advantages of the nepheloid layers that we sampled, in which yellow particles stained by DAPI were abundant: the report that such particles are rich in labile organics (Mostajir et al. 1995), the positive correlation we observed between nepheloid particle and chl a concentrations, and the significantly higher concentrations of hybridizable cells in the nepheloid layers than in deep waters (Mann-Whitney $U$-test, $\mathrm{p}=0.02$ ). However, while the nepheloid layers of the Northwest Passage had higher macro-nutrient concentrations than surface waters (Table 2), no clear nutritional advantage distinguished nepheloid layers from deep waters in our study: macronutrient, POC, PON and chl a concentrations were statistically indistinguishable between those 2 sample types. Among all the environmental variables we measured, only particle concentrations differed significantly between nepheloid layers and deep waters. It is possible that particles mediate the availability of substrate by scavenging and concentrating it on a microbially relevant scale, or by supplying it through decomposition, but our bulk measurements could not have detected these processes.

In contrast to their high representation in surface waters, CF were a small percentage of the total and hybridizable cells in nepheloid layers (medians of 3.0 and $7.3 \%$, respectively). These results are surprising, given the frequent association of $\mathrm{CF}$ with particles in other marine environments (DeLong et al. 1993, Rath et al. 1998, Crump et al. 1999), although whether that association changes with different types of particles is not well known. In fact, CF abundance in the Northwest Passage correlated negatively with particle concentration (Table 4), leaving CF distribution in the region better explained as a function of depth or of other factors with a depth-dependence, including macro-nutrient and oxygen concentrations (to which CF correlated with high significance; Table 4). Overall, CF appeared to be more competitive in surface environments supporting larger cell populations and supplies of available organic substrate (as reflected by the positive correlation between $\mathrm{CF}$ as a percentage of total cells and chl a concentration; Table 4). We cannot exclude the possibility, however, that CF319a failed to hybridize with some of the CF: a recent study indicated that less than $50 \%$ of epilithic CF in a clone library were detected by this probe (O'Sullivan et al. 2002).

Unlike the $\mathrm{CF}$, Archaea were enriched in nepheloid layers, where the archaeal fraction of hybridizable cells correlated positively and significantly with particle concentration. Thus, the Archaea were specifically associated with the only physical-chemical feature that distinguished nepheloid layers from deep waters in our study. Whether this reflects the particle source or selection for Archaea in nepheloid layers remains unclear. That archaeal concentration (and percentage of both total and hybridizable cells) over the entire data set correlated positively with high significance to particle concentrations (Table 4) strongly suggests a specific link of these Archaea to particles and the pelagic environments where the particles accumulate. Crump \& Baross (2000) reported high diversity of Archaea associated with particles in the turbidity maximum of the Columbia River estuary, but archaeal abundance was not measured and they ultimately concluded that the Archaea were largely allochthonous. Although a distant source may also pertain in this study, allochthony does not preclude the possible involvement of the Archaea associated with nepheloid layers in pelagic processes of the Northwest Passage. The highly significant correlation ( $\mathrm{r}=0.97, \mathrm{p}<0.001)$ between abundance of Archaea and PON concentration in nepheloid layers in this study, the frequent importance of nepheloid layers or estuarine turbidity maxima to nitrogen cycling in the water column (e.g. Owens 1986, Balls et al. 1996, Abril et al. 2000, Brion et al. 2000), and the significant correlations of both the Group I and II Archaea with nitrite in the Santa Barbara time series (Murray et al. 1999b) all suggest the involvement of some of the planktonic Archaea in the marine nitrogen cycle, possibly as denitrifiers (Sinninghe Damste et al. 2002) or nitrifiers.

A final, general observation on archaeal distribution comes from analysis of the entire data set. The abundance of Archaea increased significantly as the concentrations of chl $a$, total cells and Bacteria decreased. It also decreased with hybridizable cell concentrations (Fig. 3) and correlated significantly but oppositely with the same environmental variables, including particle concentration, as the Bacteria, CF and total cell concentrations (Table 4). Negative correlations with total cell abundance and chl a have also been observed in other data sets (e.g. Murray et al. 1998, 1999b) and might be considered diagnostic of the planktonic Archaea, especially the Group I Crenarchaeota (Massana et al. 1997, 1998). 


\section{CONCLUSIONS}

In this study of the distribution and diversity of bacterioplankton in the western region of the Northwest Passage, the abundances of Bacteria, CF and Archaea were determined in surface waters, nepheloid layers and deep waters during an oligotrophic period in late summer. Results for surface waters reaffirmed the numerical importance of $\mathrm{CF}$ in cold, high latitude marine environments and correspondingly low numbers of surface-water Archaea. CF were considerably less abundant in the nepheloid layers of the region, in spite of the well-known proclivity of CF for particles. Instead, nepheloid layers were enriched in Archaea. This specific association of Archaea with particle-rich waters and the significant positive correlation of Archaea to particle concentration region-wide reveal a previously unrecognized niche for marine Archaea that may hold important clues to their biogeochemical functions.

Acknowledgements. This research was supported by the Research Royalty Fund of the University of Washington (J.W.D.), an NDSEG fellowship (L.E.W.) and the UW Astrobiology Program. We are grateful to E. Carmack for the opportunity to participate in the expedition, F. McLaughlin for her role as chief scientist, the crew and officers of the 'Sir Wilfrid Laurier', K. Krogslund (UW), L. White (IOS, Sydney, BC), and M. O'Brien (IOS) for CHN, macro-nutrient, salinity and oxygen analyses, respectively, and A. Balsom for the chl a data (NSF grant OPP-003241, PI J. Grebmeier, University of Tennessee). We also thank M. Schrenk and S. Carpenter for laboratory assistance, R. Sirius for support and insight, and anonymous reviewers who helped us to improve an earlier version of the manuscript.

\section{LITERATURE CITED}

Abril G, Riou SA, Etcheber H, Frankignoulle M, de Wit R, Middelburg JJ (2000) Transient tidal time-scale nitrogen transformation in an estuarine turbidity maximum-fluid mud system (the Gironde, south-west France). Estuar Coast Shelf Sci 50:703-715

Alfreider A, Pernthaler J, Amann R, Sattler B, Glockner FO, Wille A, Psenner R (1996) Community analysis of the bacterial assemblages in the winter cover and pelagic layers of a high mountain lake by in situ hybridization. Appl Environ Microbiol 62:2138-2144

Amann RI, Binder BJ, Olson RJ, Chisholm SW, Devereux R, Stahl DA (1990) Combination of 16S rRNA-targeted oligonucleotide probes with flow cytometry for analyzing mixed microbial populations. Appl Environ Microbiol 56: 1919-1925

Amann RI, Ludwig W, Schleifer KH (1995) Phylogenetic identification and in situ detection of individual microbial cells without cultivation. Microbiol Rev 59:143-169

Azetsu-Scott K, Johnson BD, Petrie B (1995) An intermittent, intermediate nepheloid layer in Emerald Basin, Scotian Shelf. Cont Shelf Res 15:281-293

Balls PW, Brockie N, Dobson J, Johnston W (1996) Dissolved oxygen and nitrification in the Upper Forth estuary during summer (1982-1992): patterns and trends. Estuar Coast Shelf Sci 42:117-134

Bano N, Hollibaugh JT (2002) Phylogenetic composition of bacterioplankton assemblages from the Arctic Ocean. Appl Environ Microbiol 68:505-518

Boetius A, Springer B, Petry C (2000) Microbial activity and particulate matter in the benthic nepheloid layer (BNL) of the deep Arabian Sea. Deep-Sea Res II 47:2687-2706

Brachvogel T, Schweitzer B, Simon M (2001) Dynamics and bacterial colonization of microaggregates in a large mesotrophic lake. Aquat Microb Ecol 26:23-35

Brion N, Billen G, Guezennec L, Ficht A (2000) Distribution of nitrifying activity in the Seine River (France) from Paris to the Estuary. Estuaries 23:669-682

Carmack EC, Macdonald RW (2002) Oceanography of the Canadian Shelf of the Beaufort Sea: a setting for marine life. Arctic 55 (Suppl):29-45

Checkley DM Jr, Uye S, Dagg MJ, Mullin MM, Omori M, Onbe T, Zhu MY (1992) Diel variation of the zooplankton and its environment at neritic stations in the Inland Sea of Japan and the north-west Gulf of Mexico. J Plankton Res $14: 1-40$

Cho BC, Azam F (1988) Major role of bacteria in biogeochemical fluxes in the ocean's interior. Nature 332:441-444

Cottrell MT, Kirchman DL (2000) Community composition of marine bacterioplankton determined by 16S rRNA gene clone libraries and fluorescence in situ hybridization. Appl Environ Microbiol 66:5116-5122

Crump BC, Baross JA (1996) Particle-attached bacteria and heterotrophic plankton in the Columbia River estuary. Mar Ecol Prog Ser 138:265-273

Crump BC, Baross JA (2000) Archaeaplankton in the Columbia River, its estuary and the adjacent coastal ocean, USA. FEMS Microbiol Ecol 31:231-239

Crump BC, Armbrust EV, Baross JA (1999) Phylogenetic analysis of particle-attached and free-living bacterial communities in the Columbia River, its estuary and the adjacent coastal ocean. Appl Environ Microbiol 65:3192-3204

Daims H, Bruehl A, Amann R, Schleifer KH, Wagner M (1999) The domain-specific probe EUB338 is insufficient for the detection of all Bacteria: development and evaluation of a more comprehensive probe set. Syst Appl Microbiol 22: 434-444

Delong EF (1992) Archaea in coastal marine environments. Proc Natl Acad Sci USA 89:5685-5689

Delong EF, Franks DG, Alldredge AL (1993) Phylogenetic diversity of aggregate-attached vs. free-living marine bacterial assemblages. Limnol Oceanogr 38:924-934

Delong EF, Wu KY, Prezelin BB, Jovine RVM (1994) High abundance of Archaea in Antarctic marine picoplankton. Nature 371:695-697

Delong EF, Taylor LT, Marsh TL, Preston CM (1999) Visualization and enumeration of marine planktonic Archaea and Bacteria by using polyribonucleotide probes and fluorescent in situ hybridization. Appl Environ Microbiol 65: $5554-5563$

Eilers, H, Pernthaler J, Glockner FO, Amann R (2000) Culturability and in situ abundance of pelagic bacteria from the North Sea. Appl Environ Microbiol 66:3044-3051

Giovannoni SJ, Britschgi TB, Moyer CL, Field KG (1990) Genetic diversity in Sargasso Sea bacterioplankton. Nature 345:60-63

Glockner FO, Amann R, Alfreider A, Pernthaler J, Psenner R, Trebesius K, Schleifer KH (1996) An in situ hybridization protocol for detection and identification of planktonic bacteria. Syst Appl Microbiol 19:403-406

Glockner FO, Fuchs BM, Amann R (1999) Bacterioplankton 
compositions of lakes and oceans: a first comparison based on fluorescent in situ hybridization. Appl Environ Microbiol 65:3721-3726

Griffiths RP, Hayasaka SS, McNamara TM, Morita RY (1978) Relative microbial activity and bacterial concentrations in water and sediment samples taken in the Beaufort Sea. Can J Microbiol 24:1217-1226

Hequette, A, Desrosiers M, Barnes PW (1995) Sea ice scouring on the inner shelf of the southeastern Canadian Beaufort Sea. Mar Geol 128:201-219

Hill PR, Nadeau OC (1989) Storm-dominated sedimentation on the inner shelf of the Canadian Beaufort Sea. J Sediment Petrol 59:455-468

Huston AL, Deming JW (2002) Relationship between microbial extracellular enzymatic activity and suspended and sinking particulate organic matter: Seasonal transformations in the North Water. Deep-Sea Res II 49:5211-5225

Iseki K, Macdonald RW, Carmack EC (1987) Distribution of particulate matter in the southeastern Beaufort Sea in late summer. Proc NIPR Symp Polar Biol 1:35-46

Junge K, Imhoff JF, Staley JT, Deming JW (2002) Phylogenetic diversity of numerically important Arctic sea-ice bacteria cultured at subzero temperature. Microb Ecol 43: 315-328

Kamykowski D, Bird JL (1981) Phytoplankton associations with the variable nepheloid layer on the Texas continental shelf. Estuar Coast Shelf Sci 13:317-326

Karner M, Fuhrman JA (1997) Determination of active marine bacterioplankton: a comparison of universal 16S rRNA probes, autoradiography and nucleoid staining. Appl Environ Microbiol 63:1208-1213

Karner MB, Delong EF, Karl DM (2001) Archaeal dominance in the mesopelagic zone of the Pacific Ocean. Nature 409: 507-510

Kemp PF, Lee S, Laroche J (1993) Evaluating bacterial activity from cell-specific ribosomal RNA content measured with oligonucleotide probes. In: Kemp PF, Sherr BF, Sherr EB, Cole JJ (eds) Handbook of methods in aquatic microbial ecology. Lewis Publishers, Boca Raton, p 415-422

Kirchman DL (2002) The ecology of Cytophaga-Flavobacteria in aquatic environments. FEMS Microbiol Ecol 39:91-100

Li WKW, Dickie PM (1984) Rapid enhancement of heterotrophic but not photosynthetic activities in Arctic microbial plankton at mesobiotic temperatures. Polar Biol 3:217-226

Macdonald RW, Carmack EC, Mclaughlin FA, Iseki K, Macdonald DM, O'Brien MO (1989) Composition and modification of water masses in the Mackenzie Shelf estuary. J Geophys Res 94:18 057-18070

Macdonald RW, Solomon SM, Cranston RE, Welch HE, Yunker MB, Gobeil C (1998) A sediment and organic carbon budget for the Canadian Beaufort Sea. Mar Geol 144:255-273

Manz W, Amann R, Ludwig W, Vancanneyt M, Schleifer KH (1996) Application of a suite of 16S rRNA-specific oligonucleotide probes designed to investigate bacterium of the phylum Cytophaga-Flavobacter-Bacteroides in the natural environment. Microbiology (Reading) 142:1097-1106

Maruyama A, Sunamura M (2000) Simultaneous direct counting of total and specific microbial cells in seawater using a deep-sea microbe as target. Appl Environ Microbiol 66: 2211-2215

Massana R, Murray AE, Preston CM, Delong EF (1997) Vertical distribution and phylogenetic characterization of marine planktonic Archaea in the Santa Barbara Channel. Appl Environ Microbiol 63:50-56

Massana R, Taylor LT, Murray AE, Wu KY, Jeffrey WH,
Delong EF (1998) Vertical distribution and temporal variation of marine planktonic archaea in the Gerlache Strait, Antarctica, during early spring. Limnol Oceanogr 43: $607-617$

McCave IN (1986) Local and global aspects of the bottom nepheloid layers in the world ocean. Neth J Sea Res 20: 167-181

Morita RY (1997) Bacteria in oligotrophic environments: starvation-survival lifestyle. Chapman and Hall, New York

Mostajir B, Dolan JR, Rassoulzadegan F (1995) A simple method for the quantification of a class of labile marine pico- and nano-sized detritus: DAPI yellow particles (DYP). Aquat Microb Ecol 9:259-266

Murray AE, Preston CM, Massana R, Taylor LT, Blakis A, Wu K, Delong EF (1998) Seasonal and spatial variability of bacterial and archaeal assemblages in the coastal waters near Anvers Island, Antarctica. Appl Environ Microbiol 64:2585-2595

Murray AE, Wu KY, Moyer CL, Karl DM, Delong EF (1999a) Evidence for circumpolar distribution of planktonic Archaea in the Southern Ocean. Aquat Microb Ecol 18: 263-273

Murray AE, Blakis A, Massana R, Strawzewski S, Passow U, Alldredge A, Delong EF (1999b) A time series assessment of planktonic archaeal variability in the Santa Barbara Channel. Aquat Microb Ecol 20:129-145

Omstedt A, Carmack EC, Macdonald RW (1994) Modeling the seasonal cycle of salinity in the Mackenzie shelf/ estuary. J Geophys Res 99:10 011-10 021

O'Sullivan LA, Weightman AJ, Fry JC (2002) New degenerate Cytophaga-Flexibacter-Bacteroides-Specific $16 \mathrm{~S}$ ribosomal DNA-targeted oligonucleotide probes reveal high bacterial diversity in River Taff epilithon. Appl Environ Microbiol 68:201-210

Ouverney CC, Fuhrman JA (2000) Marine planktonic Archaea take up amino acids. Appl Environ Microbiol 66: 4829-4833

Owens NJP (1986) Estuarine nitrification: a naturally occurring fluidized bed reaction? Estuar Coast Shelf Sci 22: 31-44

Palumbo AV, Ferguson RL, Rublee PA (1984) Size of suspended bacterial cells and association of heterotrophic activity with size fractions of particles in estuarine and coastal waters. Appl Environ Microbiol 48:157-164

Parsons TR, Webb DG, Dovey H, Haigh R, Lawrence M, Hopky GE (1988) Production studies in the Mackenzie River - Beaufort Sea estuary. Polar Biol 8:235-239

Parsons TR, Webb DG, Rokeby BE, Lawrence M, Hopky GE, Chiperzak DB (1989) Autotrophic and heterotrophic production in the Mackenzie River/Beaufort Sea estuary. Polar Biol 9:261-266

Pomeroy LR, Deibel D (1986) Temperature regulation of bacterial activity during the spring bloom in Newfoundland coastal waters. Science 233:359-361

Pomeroy LR, Wiebe WJ (2001) Temperature and substrates as interactive limiting factors for marine heterotrophic bacteria. Aquat Microb Ecol 23:187-204

Pomeroy LR, Macko SA, Ostrom PH, Dunphy J (1990) The microbial food web in Arctic seawater: concentration of dissolved free amino acids and bacterial abundance and activity in the Arctic Ocean and in Resolute Passage. Mar Ecol Prog Ser 117:259-268

Preston CM, Wu KY, Molinski TF, Delong EF (1996) A psychrophilic crenarchaeon inhabits a marine sponge: Cenarchaeum symbiosum gen. nov., sp. nov. Proc Natl Acad Sci USA 93:6241-6246 
Rath J, Wu KY, Herndl GJ, Delong EF (1998) High phylogenetic diversity in marine-snow-associated bacterial assemblage. Aquat Microb Ecol 14:261-269

Ravenschlag K, Sahm K, Amann R (2001) Quantitative molecular analysis of the microbial community in marine Arctic sediments (Svalbard). Appl Environ Microbiol 67:387-395

Reimnitz E, Kempema EW, Barnes PW (1987) Anchor ice, seabed freezing, and sediment dynamics in shallow Arctic seas. J Geophys Res 92:14 671-14678

Ritzrau W, Graf G (1992) Increase of microbial biomass in the benthic turbidity zone of Kiel Bight after resuspension by a storm event. Limnol Oceanogr 37:1081-1086

Ritzrau W, Thomsen L (1997) Spatial distribution of particle composition and microbial activity in benthic boundary layer (BBL) of the Northeast Water Polynya. J Mar Syst 10: 415-428

Ritzrau W, Thomsen L, Lara RJ, Graf G (1997) Enhanced microbial utilisation of dissolved amino acids indicates

Editorial responsibility: James Hollibaugh,

Athens, Georgia, USA rapid modification of organic matter in the benthic boundary layer. Mar Ecol Prog Ser 156:43-50

Sinninghe Damste JS, Rijpstra WIC, Hopmans EC, Prahl FG, Wakeham SG, Schouten S (2002) Distribution of membrane lipids of planktonic Crenarchaeota in the Arabian Sea. Appl Environ Microbiol 68:2997-3002

Stahl DA, Amann R (1991) Development and application of nucleic acid probes. In: Stackebrandt E, Goodfellow M (eds) Nucleic acid techniques in bacterial systematics. Wiley-Liss Inc., New York, p 205-248

Townsend DW, Mayer LM, Dortch Q, Spinrad RW (1992) Vertical structure and biological activity in the bottom nepheloid layer of the Gulf of Maine. Cont Shelf Res 12: 367-387

Yager PL, Connelly TL, Mortazavi B, Wommack KE, Bano N, Bauer JE, Opsahl S, Hollibaugh JT (2001) Dynamic bacterial and viral response to an algal bloom at subzero temperatures. Limnol Oceanogr 46:790-801

Submitted: March 20, 2002; Accepted: October 24, 2002

Proofs received from author(s): January 30, 2003 